Margot van Mulken en

Peter Jan Schellens

\title{
Over loodzware bassen en wapperende broekspijpen. Gebruik en perceptie van taalintensiverende stijlmiddelen
}

\section{Inleiding}

In een essay uit 2007 beklaagt Marita Mathijsen zich over het gebrek aan historisch besef in de omgang met ons verleden.* Over Hoog Catharijne in Utrecht laat zij zich als volgt uit:

Utrecht is met Hoog Catharijne de grootste zonde die ooit tegen de historie van een stad gepleegd is. De naam alleen al duidt aan wat voor cynici het waren die hier met een staafmixer door het verleden gegaan zijn. Wat een hybris om een namaakhistorische naam te gebruiken voor dit product van wansmaak, grove commercie, botte economie, minachting voor esthetiek, walging van schoonheid en verheerlijking van consumptie van de goedkoopste soort! Patatbouw in een krokettencomplex. (Mathijsen, 2007, p.1516.)

Het is duidelijk dat Mathijsen het winkelcentrum niet erg mooi vindt. Zij betreurt dat het oude stationskwartier ervoor is afgebroken en de Catharijnesingel gedempt. Ook de naam van het winkelcentrum bevalt haar niet. Maar bij die min of meer zakelijke evaluaties blijft het niet. Door haar woordkeuze (o.a. de grootste zonde ooit, cynici met hybris, minachting, walging, botte economie) en het gebruik van beeldspraak (o.a. de staafmixer door het verleden halen, patatbouw in een krokettencomplex) zet

Tijdschrift voor Taalbeheersing - 34 (2012), nr. 1, 28-55

\begin{abstract}
Samenvatting
Taalgebruikers kunnen hun evaluatieve uitingen kracht bij zetten met stilistische middelen. Ze maken bijvoorbeeld gebruik van intensiverende prefixen (gloednieuw), of intensiverende beeldspraak (opmars in plaats van toename). In een corpusanalytisch onderzoek is nagegaan hoe recensies en hoofdredactionele commentaren verschillen in het gebruik van dergelijke intensiveerders. In commentaren wordt significant meer gebruik gemaakt van bijwoorden van graad en versteende beeldspraak. In recensies treffen we meer intensiverende voorvoegsels, bijvoeglijke naamwoorden en originele beeldspraak aan. Maar merken taalgebruikers dergelijke stilistische versterkingen wel op? In twee experimenten kregen proefpersonen tekstfragmenten met en zonder intensiveringen voorgelegd. Taalgebruikers bleken de geïntensiveerde evaluaties inderdaad krachtiger en subjectiever te vinden dan de niet geïntensiveerde uitingen. Voor een betrouwbare identificatie van intensiverende elementen is nog geen in alle opzichten bevredigende oplossing gevonden. In de discussie gaan we in op de vraag hoe met de (on)betrouwbaarheid van interpretatieve data in een corpusanalyse kan worden omgegaan.
\end{abstract}




\section{Over loodzware bassen en wapperende broekspijpen}

zij haar standpunt kracht bij. Ongetwijfeld wil zij haar standpunt niet alleen fraai maar ook overtuigend onder woorden te brengen. Lukt dat op deze manier?

In onderzoek naar beïnvloedingsprocessen heeft het verschijnsel language intensity gedurende een aantal decennia aandacht gekregen. De resultaten van experimenteel onderzoek naar het effect van taalintensiteit op de overtuigingskracht van persuasieve boodschappen zijn niet eenduidig. Soms werkt het. (Zie bijvoorbeeld Buller et al., 2000a en b.) Soms werkt het niet. (Zie bijvoorbeeld Hornikx, Pieper \& Schellens, 2008.) Belangrijke intermediërende variabelen lijken de aanvankelijke afstand in opinie tussen boodschap en ontvanger en de geloofwaardigheid van de bron (Hamilton, Hunter \& Burgoon, 1990). De afstand tussen boodschap en ontvanger zou Marita Mathijsen parten kunnen spelen. Haar krachtige uitspraken zijn vermoedelijk overtuigend voor wie al niet erg enthousiast was over dit winkelcentrum. Wie er echter naar volle tevredenheid zijn wekelijkse boodschappen doet bijV\&D en daarna op weg naar het centraal station een kroketje haalt, zal niet snel door een dergelijke uitgesproken mening overtuigd worden. Ook de geloofwaardigheid van de bron kan hier een mediërende rol spelen. De krachtige taal zal positief uitwerken voor degenen die Marita Mathijsen als hoogleraar historische letterkunde een geloofwaardige autoriteit vinden op het terrein van ons nationale erfgoed. Wie echter van mening is dat een historisch letterkundige niet al te veel gezag moet worden toegekend op het gebied van stedelijke planologie, zal door haar krachtig uitgesproken standpunt niet gemakkelijk over de streep worden getrokken.

De vraag naar het effect van een krachtige of intensieve stijl blijkt ingewikkeld. Bovendien hebben we geen goed zicht op de stilistische middelen waarmee de intensiteit van een tekst kan worden vergroot of verkleind. Het gevolg daarvan is dat de intensiteit van teksten in experimenteel onderzoek op heel verschillende manieren wordt gemanipuleerd. We stellen daarom in dit artikel twee preliminaire vragen centraal: met welke middelen kan de intensiteit van taal worden verhoogd en worden die middelen door taalgebruikers wel voldoende opgemerkt om er überhaupt effect van te mogen verwachten?

\section{Taalintensiteit en taalintensivering}

Bowers (1963, p.345) geeft de volgende definitie van language intensity: 'the quality of language which indicates the degree to which the speaker's attitude toward a concept deviates from neutrality.'Vrijwel alle onderzoekers na hem sluiten zich hierbij aan. De manier waarop in experimenten een hoog- en een laag-intensieve versie van eenzelfde tekst werd gecreeerd, laat echter grote verschillen zien. Zo wordt er soms niet alleen stilistisch, maar ook inhoudelijk fors ingegrepen. Hamilton, Hunter en Burgoon (1990, p.253-254) gebruiken bijvoorbeeld de volgende hoog- en laagintensieve varianten in hun experimentele materiaal:

(2) The laws regulating the sale of heroin in this country have frequently / sometimes done more harm than good (...).

It would sharply / gradually reduce the number of heroin-related deaths / injuries due to disease and overdose.

De 'intensiteit' van de uitingen wordt met frequently en deaths natuurlijk wel hoger dan met sometimes en injuries, maar dat valt moeilijk op te vatten als een taalkundig, laat staan een stilistisch verschijnsel. De inhoud van de boodschap wordt hiermee ingrijpend veranderd. $\mathrm{Nu}$ verandert een stilistische ingreep ook altijd iets aan de inhoud van een tekst. Wie een voorstel een waardeloos idee noemt in plaats van een slecht idee, zegt uiteraard iets anders, maar de 
inhoudelijke verschuiving zit hem vooral in de kracht van de evaluatie, niet in de empirische stand van zaken die in de uiting wordt geëvalueerd. Wij willen de term taalintensiteit graag reserveren voor het stilistische verschijnsel. (Vergelijk Hamilton \& Hunter, 1998.)

Ook de termen taalintensivering en intensiveerder zijn soms aanleiding tot verwarring. De intensiteit van een uiting kan door een stilistische keuze hoger of lager worden. Zowel intensiveerders (ontzettend slordig) als afzwakkers of extensiveerders (een beetje slordig) geven uitdrukking aan de kracht van een evaluatie. Beide verschijnselen vallen natuurlijk onder taalintensiteit, net als verwarming en afkoeling onder het verschijnsel temperatuur kunnen worden gerangschikt. Soms worden echter zowel versterkers als afzwakkers onder intensivering geschaard. Zo gebruiken Martin en White (2005, p. 141-148) de term intensification voor zowel up-scaling als down-scaling en noemen zij zowel completely als slightly intensifiers. Pander Maat (2004) rekent ook het afzwakken van negatiefgewaardeerde getallen (slechts 2 miljoen) onder de intensiveerders. Dat vinden we verwarrend. Weliswaar kan een afzwakker soms geïnterpreteerd worden als een understatement en daarmee de betekenis van een versterker krijgen (een beetje dom krijgt dan de interpretatie ontzettend dom). Dat is echter geen reden om alle afzwakkers intensiveerders te noemen.

Een tweede onderscheid dat gemaakt moet worden is dat tussen intensivering en subjectivering.Vergelijk:

a. Dat is een boek

b. Dat is een goed leesbaar boek

c. Dat boek leest als een trein

$$
\begin{aligned}
& \text { Het bedrijf boekte de afgelopen jaren } \\
& \text { a. een winst van } 10 \text { miljoen euro } \\
& \text { b. een mooie winst van } 10 \text { miljoen euro } \\
& \text { c. een vorstelijke winst van } 10 \text { miljoen euro }
\end{aligned}
$$

De a-zinnen bevatten geen evaluatie. De b-zinnen wijken daarvan af doordat hierin een (positieve) evaluatie van de spreker/schrijver tot uitdrukking komt. In de c-zinnen is die positieve evaluatie nog verstrekt door een andere woordkeuze. In onze analyse zijn goed leesbaar en mooie weliswaar evaluatieve uitdrukkingen maar géén intensiveringen. Zij drukken een evaluatie van de spreker/schrijver uit en maken daarmee de uiting subjectief en persoonlijker dan de a-uitingen. Leest als een trein en vorstelijk beschouwen we wél als intensiveringen, omdat zij een positieve evaluatie op een versterkte manier tot uitdrukking brengen. Ook hier zullen in concrete gevallen de scheidslijnen niet altijd glashelder zijn. Zo veronderstellen wij dat in vorstelijke een krachtiger evaluatie tot uitdrukking komt dan in mooie, maar dat is uiteraard een kwestie van gradatie waarover niet elke hoorder hetzelfde hoeft te denken. Dergelijke interpretatieproblemen worden echter niet opgelost als we alle evaluatieve uitdrukkingen intensiveringen noemen.

Met andere woorden: evaluatieve adjectiva (zoals mooi) en evaluatieve bepalingen (zoals goed leesbaar) subjectiveren de uiting zeker: zij maken van een descriptieve uiting een evaluatieve uiting. Maar zij intensiveren de uiting niet. Niet elke subjectivering of evaluatie is tegelijkertijd intensiverend. Andersom geldt wel dat elke intensivering tegelijkertijd een (subjectieve) evaluatie inhoudt. 


\section{Over loodzware bassen en wapperende broekspijpen}

Zonder de definitie van Bowers van taalintensiteit te vervangen, definiëren wij nu taalintensivering als volgt: een element in een uiting is een intensivering wanneer het element kan worden weggelaten of vervangen met als resultaat: een grammaticaal correcte zin die in de context relevant is én een minder krachtige evaluatie tot uitdrukking brengt. ${ }^{1}$

Soorten intensiveerders in eerder analytisch onderzoek naar taalintensivering

Renkema (1997), Pander Maat (2004) en Van Mulken en Schellens (2006) deden eerder tekstanalytisch onderzoek naar taalintensiteit. Renkema en Pander Maat ontwikkelden een eigen analyseschema.Van Mulken en Schellens gebruikten de analyseschema's van Renkema en Pander Maat in een vergelijkend onderzoek.

Renkema definieert een intensiveerder als 'een formulering die vervangen kan worden door een afgezwakte variant' (p. 497). Hij onderscheidt drie hoofdcategorieën, afhankelijk van de ingreep waarmee van de intensieve versie een afgezwakte variant kan worden gemaakt. Wanneer de intensiveerder kan worden weggelaten (uiterst zeldzaam > zeldzaam), is er sprake van een lexicale intensiveerder. Wanneer vervanging van de intensiveerder door een zwakkere uitdrukking nodig is (een schitterend landschap $>$ een mooi landschap), spreekt Renkema van een semantische intensiveerder. Wanneer ten slotte voor de afzwakking een stijlfiguur moet worden herschreven tot 'gewoon', niet-figuurlijk proza (Hij bezat kind noch kraai> Hij bezat niets), spreekt Renkema van een stilistische intensiveerder. ${ }^{2}$

Renkema onderscheidt ook nog 18 subcategorieën. Onder lexicale intensiveerders vallen de subcategorieën: basisversterker (incl. prefixen) (zeer, overvol), tijdaanduiding (pas vier uur, zelden), plaatsaanduiding (tot in de kleinste uithoeken), kwantificator (bijna iedereen), kwalificator (echt gelogen, de onstuimige zee), preciseerder (exact, met name) en onverwachtheidspartikel (maar liefst, zelfs). De semantische intensiveerders onderscheidt Renkema op basis van woordsoort: verba (gekelderd $>$ gedaald), nomina (blamage $>$ schande), adjectiva (kolossaal $>$ groot) en adverbia (behoorlijk $>$ enigszins). Onder de stilistische intensiveerders vallen een aantal stijlfiguren: herhaling (het was heet, heet, heet!), tautologie (nooit ofte nimmer), pleonasme (de uiterste limiet), climax (hij wachtte uren, dagen, maanden), litotes (hij schrijft niet onaardig), vergelijking (ze gingen als wilde beesten tekeer) en metafoor (het onderspit delven). (Zie Renkema 1997, p. 497-498, ook de voorbeelden ontlenen we aan hem).

In Renkema's voorstel vallen ons twee dingen op. Ten eerste worden de semantische intensiveerders ingedeeld op basis van woordsoort. De lexicale intensiveerders worden echter op een andere basis ingedeeld, hoewel uit de voorbeelden blijkt dat het hier naast prefixen voornamelijk om adverbia of adverbiale bepalingen (zeer, puur, maarliefst) gaat en een enkele keer om adjectiva (een onstuimige zee, een snelle afdaling).

Ten tweede lijkt ons de grens tussen weglaatbaarheid en vervangbaarheid (en dus tussen lexicale en semantische intensiveerders, niet altijd even scherp. Als we 'de onstuimige zee' vervangen door 'de zee', is onstuimige een lexicale intensiveerder (zoals Renkema voorstelt). Als we 'de onstuimige zee' vervangen door 'de onrustige zee', is het echter een semantische intensiveerder. Omgekeerd: als we 'hij was behoorlijk dronken' vervangen door 'hij was enigszins dronken', is behoorlijk een semantische intensiveerder (zoals Renkema voorstelt). Als we 'hij was behoorlijk dronken' vervangen door 'hij was dronken', is behoorlijk een lexicale intensiveerder. De indeling in categorieën is daarmee afhankelijk van de inventiviteit van de codeur. Het is de vraag of weglaatbaarheid versus vervangbaarheid dan wel als fundamentum divisionis moet worden gebruikt om twee hoofdcategorieën van elkaar te onderscheiden. 
Pander Maat $(2004,2007)$ deed onderzoek naar het lot van wat hij noemt 'wervende elementen' in persberichten. Voor ons is interessant dat Pander Maat voor de definitie van 'wervend element' aansluit bij het verschijnsel taalintensivering:

Een wervend element intensiveert een uitspraak in een richting die gunstig is voor de zender van de tekst. Intensivering wordt hier gedefinieerd als argumentatieve versterking in de zin van Ducrot (1980): een geïntensiveerde uitspraak vormt een sterker argument voor een bepaalde conclusie dan een niet geïntensiveerde uitspraak. (Pander Maat 2004, p. 210)

Ook Pander Maat onderkent dat intensiverende elementen soms kunnen worden weggelaten en soms alleen kunnen worden vervangen, maar hij gebruikt dat niet als basis voor zijn indeling. Hij onderscheidt vier hoofdcategorieën op grammaticale gronden: intensiverende voorvoegsels (hypermodern, gloednieuw), adjectieven (toonaangevend verschil > verschil), adverbiale elementen (enorm groot $>$ groot) en verbindingswoorden (bovendien $>$ ook/en, niet alleen - maar ook). In de adjectiva en adverbiale elementen onderscheidt Pander Maat nog een aantal subcategorieën. Hij maakt onderscheid tussen: versterkende adjectieven (belangrijk, groot), evaluatieve adjectieven (geweldig, uniek), andere adjectieven (betrouwbaar, duidelijk), intensiverende hoeveelheidsaanduiders (alle, extra), vergelijkende en overtreffende trappen (belangrijkste). Onder de adverbiale elementen schaart hij: adverbiale intensiveringen (enorm, aanzienlijk), temporele bijwoorden (reeds, eens temeer), bijwoorden die verwijzen naar plaatsen (wereldwijd), intensiveringen voorafgaand aan getallen (ruim, meer dan), verzwakkingen van negatief gewaardeerde getallen (slechts, minder dan) en modale intensiveringen (natuurlijk, simpelweg).

In het voorstel van Pander Maat valt in vergelijking met dat van Renkema het volgende op. Ten eerste zijn zijn hoofdcategorieën gebaseerd op een onderscheid in woordsoorten. In afwijking van Renkema komen intensiverende verba en nomina bij Pander Maat echter niet voor. Evenmin onderscheidt hij stijlfiguren als intensiverend of wervend element.

Ten tweede makt Pander Maat in tegenstelling tot Renkema bij adjectiva een aantal semantisch getinte onderscheidingen. De etiketten spreken hier niet voor zich. Pander Maat makt onderscheid tussen adjectiva die de interpretatie van het substantief versterken (een groot verschil), adjectiva die verwijzen naar positieve evaluaties zonder de eigenschap te noemen waarop deze evaluatie is gebaseerd (een geweldige act) en andere adjectiva die verwijzen naar specifieke eigenschappen (een duidelijk verhaal). De grenzen daartussen zijn ons niet altijd duidelijk. Zo zien wij geen helder verschil tussen een groot, een geweldig en een duidelijk verschil, in alle drie de gevallen krijgt het adjectief waarschijnlijk de interpretatie groot. Daarnaast onderscheidt Pander Maat op morfologische gronden de vergelijkende en overtreffende trap. De hoeveelheidaanduiders lijken ons eerder bij adverbia thuis te horen.

Ten derde makt Pander Maat bij de adverbia een aantal onderscheidingen die grofweg overeenkomen met de onderscheidingen van Renkema in de hoofdcategorie lexicale intensiveringen. De basisversterkers, de tijd- en plaatsaanduidingen en de onverwachtheidspartikels van Renkema zien we terugkomen als adverbiale intensiveringen, temporele bijwoorden, bijwoorden van plaats en modale intensiveringen bij Pander Maat.

We vermoeden dat het eerste verschil tussen Renkema en Pander Maat voortkomt uit de verschillende soorten teksten die zij analyseerden. Renkema's corpus bestond uit zakelijke en 


\section{Over loodzware bassen en wapperende broekspijpen}

beeldende verhaaltjes waarin zijn proefpersonen een tweetal strips navertelden. Pander Maat analyseerde persberichten uit de luchtvaartsector. Dat we bij Pander Maat geen intensiverende nomina, verba en stijlfiguren aantreffen, betekent mogelijk dat dergelijke intensiveringen in de geanalyseerde persberichten niet of nauwelijks werden gebruikt.

De behoefte aan onderscheidingen in de categorie adjectiva kan bij Pander Maat voortvloeien uit de hoge frequentie ervan ( $54 \%$ van zijn wervende elementen zijn adjectiva). En dat hangt naar onze taxatie mogelijk samen met het genre dat hij onderzocht én zijn focus op wervende elementen. In een persbericht probeert de voorlichter van een organisatie het nieuws uit zijn organisatie zo onder woorden te brengen dat de journalist geïnteresseerd raakt. Om zijn organisatie er goed in voor te stellen, kan hij hier en daar een adjectief toevoegen waarin een positieve evaluatie van het nieuws doorklinkt (in de hoop dat de journalist die positieve evaluatie overneemt). Die adjectieven kleuren of subjectiveren het persbericht, maken het wervender, maar intensiveren zij het ook? Pander Maat meldt ook dat de wervende elementen meestal kunnen worden weggelaten. Dat geldt altijd voor zijn adjectiva (met uitzondering voor de vergelijkende en overtreffende trappen). Dat duidt er volgens ons op dat de adjectiva eerder subjectiveringen dan intensiveringen waren. In een persbericht kan een mooie winst van 10 miljoen zonder problemen worden gereduceerd tot een winst van 10 miljoen. Het persbericht wordt er niet minder intensief door. Het wordt er zakelijk van in plaats van gekleurd. Datzelfde zou in een recensie niet kunnen.Vervangen we een mooi boek hier door een boek, dan verdwijnt de evaluatie uit de uiting. De recensie houdt op een recensie te zijn.

Zowel Renkema als Pander Maat is het uiteindelijk niet te doen om de intensiveringen. Renkema analyseert intensiveringen om een verschil op het spoor te komen tussen beeldende en zakelijke beschrijvingen van een strip. Pander Maat gaat het om een beschrijving van wervende elementen in zakelijke persberichten. Zij gaan er kennelijk vanuit dat intensiveringen een tekst beeldend of wervend kunnen maken. Daarin hebben zij waarschijnlijk gelijk. Maar daarmee is niet gezegd dat elk beeldend element een tekst intensiveert of elke intensivering een tekst beeldender maakt. Dat beweert Renkema overigens ook niet. Evenmin is elk wervend element een intensivering en makt elke intensivering een tekst wervender. Dat beweert Pander Maat overigens wél, gezien zijn definitie van wervend element (zie boven).

Van Mulken en Schellens (2006) maakten van de analyseschema's van Renkema en Pander Maat gebruik om zicht te krijgen op het voorkomen van verschillende soorten intensiveerders en om de bruikbaarheid en betrouwbaarheid van de analyseschema's te kunnen vergelijken. Zij analyseerden een corpus bestaande uit twee persuasieve genres: recensies en hoofdredactionele commentaren. In beide genres makt evaluatie per definitie deel uit van de tekst. In recensies wordt een artistiek product geëvalueerd; in commentaren wordt recent nieuws en/of de politieke reactie daarop geëvalueerd.Van Mulken en Schellens analyseerden 15 recensies en 15 commentaren uit twee landelijke kranten.

Het meest in het oog springende resultaat was de gebrekkige overeenstemming tussen twee codeurs. Bij gebruik van het analyseschema van Renkema waren twee codeurs het in $44 \%$ van de gevallen eens over de identificatie van een intensiveerder. Van de in totaal gevonden intensiveerders werd dus 56\% door slechts één codeur geïdentificeerd. Bij gebruik van het analyseschema van Pander Maat was de overeenstemming nog iets lager: slechts 36\% 
van de gevonden intensiveringen werd door beide codeurs onafhankelijk van elkaar geïdentificeerd. De toewijzing van intensiveringen aan verschillende categorieën verliep beter. In beide analyses was de overeenstemming matig/redelijk (Cohen's $\kappa=.59$ voor de analyse volgens Renkema; Cohen's $\kappa=.57$ voor de analyse volgens Pander Maat).

\section{Een nieuw analyseschema}

Zowel uit de inhoudelijke vergelijking van de analyseschema's van Renkema (1997) en Pander Maat (2004), als uit de vergelijkende toepassing van beide schema's op hetzelfde materiaal door Van Mulken en Schellens (2006), kunnen we maar één conclusie trekken. Er is behoefte aan een nieuw analyseschema, dat ons in staat stelt intensiveringen met een hogere mate van betrouwbaarheid te identificeren en categoriseren. Daarin zal een strakkere omschrijving moeten worden gegeven van intensivering én moeten onderscheiden categorieën scherper worden afgebakend. Bij een voorstel daartoe willen we de verdiensten van beide schema's zo goed mogelijk combineren.

- We handhaven de categorie intensiverende stijlfiguren van Renkema. Daarin maken we plaats voor de meest frequent gebruikte stijlfiguren naast een categorie 'overige stijlfiguren'.

- De andere categorieën delen we in op basis van woordsoort (zoals Renkema inconsequent en Pander Maat onvolledig deed), we maken geen onderscheid tussen weglaatbare en vervangbare intensiveringen. Om daarbij te ontsnappen aan verwarrende indelingen die mogelijk te veel en ad hoc aan het onderzochte materiaal zijn ontleend, baseren we ons daarbij op de onderscheidingen in de traditionele grammatica, in casu de Algemene Nederlandse Spraakkunst (de zogenaamde ANS van Haeseryn e.a., 1997).

Onder een intensivering verstaan we zoals gezegd: een tekstelement dat in een uiting kan worden weggelaten dan wel vervangen door een andere formulering met in beide gevallen als resultaat: een minder krachtige evaluatieve uiting die grammaticaal correct en in de context relevant is. Niet elke evaluerend element is dus intensiverend. Er moet een minder krachtige uiting mogelijk zijn. Een 'element' kan een woord zijn, maar ook een woorddeel (zoals bij prefixen) of een woordgroep (zoals bij beeldspraak, adverbiale bepalingen of werkwoordelijke uitdrukkingen). In Box 1 zijn de door ons onderscheiden categorieën te vinden, elk met een of twee voorbeelden. ${ }^{3}$ (Bijlage 1 bevat de volledige codeerinstructie.)

\section{Box 1}

Soorten intensiveringen volgens het Taal IntensiteitsModel (TIM)

Voorvoegsel

Bijwoord

- Bijwoord

- Bijwoord

- Bijwoord

- Adverbiaal

- Overige

Telwoord

Bijvoeglijk naamwoord

Zelfstandig naamwoord topatleet

hartstikke

altijd

niteraard

fantastisch gedaan

wereldwijd

honderd keer gevraagd

abject

vertoning 
Over loodzware bassen en wapperende broekspijpen

Werkwoord (incl. werkwoordelijke uitdrukking)

Stijlfiguren

- Versteende beeldspraak

- Originele beeldspraak

- Herhaling

- Hyperbool

- Overige stijlfiguren

Syntactische intensiveringen

Typografie schransen, ervandoor gaan

een boom van een kerel

een echte gitaarbeul

vast en zeker

een eeuw wachten

geen verkeerd plan

zowel ... als

GEWELDIG!

\section{Vraagstelling}

We hopen natuurlijk met dit nieuwe analyseschema in staat te zijn tot een betrouwbare identificatie en categorisering van taalintensiverende stijlmiddelen. Om de vergelijking met eerder onderzoek goed mogelijk te maken analyseren we in het eerste deelonderzoek wederom een corpus recensies en hoofdredactionele commentaren. Onze vraagstelling is hierbij:

1. Kunnen taalintensiverende stijlmiddelen met het TIM betrouwbaar geïdentificeerd en gecategoriseerd worden?

2. Zijn er verschillen in het gebruik van taalintensiverende stijlmiddelen tussen recensies en hoofdredactionele commentaren?

In het tweede deelonderzoek betrekken we de lezer in de beschouwingen. De identificatie van intensiveerders door geïnstrueerde codeurs bleek in eerder onderzoek een probleem. Maar hoe zit het dan met de lezers van een tekst? Als getrainde codeurs al over intensiveringen heen lezen, is het niet onwaarschijnlijk dat 'normale' lezers er al helemaal geen oog voor hebben. In dat geval zouden lezers geen verschil in intensiteit moeten opmerken tussen een tekst met en een tekst zonder intensivering. Nu zullen ze daartoe misschien wel in staat zijn als we teksten vergelijkenderwijs aanbieden en vragen welke variant de krachtigste is, maar zien lezers ook een verschil als hoog- en laagintensieve teksten los van elkaar worden aangeboden? We zagen hierboven dat er een onderscheid gemaakt moet worden tussen de persoonlijke kleuring van een uiting, de subjectivering, en het versterken van een evaluatie, de intensivering. Worden geïntensiveerde teksten door lezers daadwerkelijk als krachtiger gezien? En ervaren lezers ook een onderscheid tussen subjectiveringen intensivering?

In het tweede deelonderzoek stellen we daarom de volgende onderzoeksvraag:

3. Percipiëren lezers een verschil in intensiteit en subjectiviteit tussen teksten met en teksten zonder intensivering?

We zullen in dit deelonderzoek verschillende categorieën uit het TIM betrekken. Het is immers niet zeker dat alle soorten intensivering door lezers op dezelfde manier worden gepercipieerd. 


\subsection{Methode}

\section{Materiaal}

Het onderzoek is opgezet als een gewijzigde replicatie van de corpusanalyse van Van Mulken en Schellens (2006). Er zijn 15 hoofdredactionele commentaren (ook wel: hoofdartikelen) en 15 recensies (vijf literatuurrecensies, vijf filmrecensies en vijf muziekrecensies) in de analyse betrokken, afkomstig uit NRC Handelsblad en de Volkskrant van 10-22 december 2007. Bij het samenstellen van het corpus is ervoor gezorgd dat de auteurs van de recensies en de onderwerpen van de artikelen verschilden. Zeven hoofdredactionele commentaren waren afkomstig uit de Volkskrant en acht uit NRC Handelsblad.Van de recensies waren er acht afkomstig uit de Volkskrant en zeven uit NRC Handelsblad. De lengte van de artikelen varieerde van 336 tot 747 woorden. Gemiddeld bestond een artikel uit 482 woorden. De lengte van de hoofdredactionele commentaren varieerde van 443 tot 515 woorden (totaal 6727 woorden), de lengte van de recensies varieerde van 336 tot 747 woorden (totaal 6913 woorden).

\section{Procedure}

Twee ervaren codeurs analyseerden de teksten onafhankelijk van elkaar op het voorkomen van intensiveringen en categoriseerden die volgens het hierboven gepresenteerde analyseschema TIM (zie Bijlage 1).

Voor de vergelijking van de twee onderzochte genres werden in eerste instantie alleen de door beide codeurs onafhankelijk van elkaar geïdentificeerde intensiveringen gebruikt. Met het oog op verschillen in de categorisering werd een tweede codeerronde ingebouwd. Hierbij kregen de codeurs naast hun eigen codering de afwijkende coderingen van de medecodeur aangeboden. Zij konden vervolgens: hun aanvankelijke codering handhaven, wijzigen in die van de medecodeur, beiden accepteren of voor een geheel nieuwe code kiezen. ${ }^{5}$ Over de resterende verschillen werd in discussie overeenstemming bereikt.

\subsection{Resultaten}

\section{Betrouwbaarheid}

In totaal identificeerden de beide codeurs onafhankelijk van elkaar 723 intensiverende elementen in de 30 teksten, waarvan er 236 door beide codeurs werden aangewezen. De interbeoordelaarsovereenstemming was daarmee zwak (33\%, Cohen's $\kappa=.13)$. Die 236 gevallen werden in de verdere analyse betrokken. De categorisering van de door beide codeurs geidentificeerde intensiveringen leverde het volgende beeld op. Alle categorieën en subcategorieën in aanmerking genomen was de interbeoordelaarsovereenstemming matig/redelijk (Cohen's $\kappa=.59$ ). Als we afzien van de subcategorieën bij intensiverende bijwoorden en stijlfiguren, is de overeenstemming goed (Cohen's $\kappa=.74$ ). $\mathrm{Na}$ de tweede codeerronde, waarin de codeurs feedback ontvingen over de categoriseringen van de medecodeur, was de overeenstemming uitstekend (Cohen's $\kappa=.91$ ). Over de resterende probleemgevallen werd in discussie overeenstemming bereikt. 


\section{Over loodzware bassen en wapperende broekspijpen}

Verschillen tussen de genres

De frequentie van taalintensiveringen in hoofdredactionele commentaren en recensies is te vinden in Tabel 1. De drie meest frequent gebruikte intensiveringen (meer dan $10 \%$ van het totaal) zijn: intensiverende bijvoeglijke naamwoorden (22.8\%), versteende beeldspraak (11 $\%)$ en bijwoorden van modaliteit (10\%).

Tabel 1: Aantal intensiveringen, geidentificeerd door beide codeurs, in hoofdredactionele commentaren en recensies

\begin{tabular}{|c|c|c|c|}
\hline Soort intensivering & Commentaar & Recensie & Totaal \\
\hline Intensiverend voorvoegsel & 3 & 11 & 14 \\
\hline Intensiverend bijwoord van graad & 15 & 5 & 20 \\
\hline Intensiverend bijwoord van frequentie of kwantiteit & 10 & 13 & 23 \\
\hline Intensiverend bijwoord van modaliteit & 13 & 11 & 24 \\
\hline Adverbiaal gebruikt bijvoeglijk naamwoord & 6 & 11 & 17 \\
\hline Overige bijwoorden & 2 & 3 & 5 \\
\hline Intensiverend telwoord & 7 & 3 & 10 \\
\hline Intensiverend bijvoeglijk naamwoord & 19 & 35 & 54 \\
\hline Intensiverend zelfstandig naamwoord & 4 & 6 & 10 \\
\hline Intensiverend werkwoord, incl werkwoordelijke uitdrukking & 4 & 7 & 11 \\
\hline Versteende beeldspraak & 21 & 5 & 26 \\
\hline Originele beeldspraak & 0 & 6 & 6 \\
\hline Herhaling & 2 & 3 & 5 \\
\hline Hyperbool & 0 & 1 & 1 \\
\hline Overige stijlfiguren & 0 & 0 & 0 \\
\hline Syntactische intensiveringen & 0 & 2 & 2 \\
\hline Typografie & 4 & 4 & 8 \\
\hline Totaal & 110 & 126 & 236 \\
\hline
\end{tabular}

Er blijkt een significant verschil tussen de onderzochte genres $\left(\chi^{2}(15)=37.49, \mathrm{p}<.01\right)^{6}$. De analyse van de adjusted standardized residuals laat zien dat de verschillen te vinden zijn bij de voorvoegsels, de bijwoorden van graad, de bijvoeglijke naamwoorden en de versteende beeldspraak. In hoofdredactionele commentaren wordt vaker gebruik gemaakt van bijwoorden van graad en versteende beeldspraak; in recensies wordt vaker geïntensiveerd met behulp van voorvoegsels, bijvoeglijke naamwoorden en originele beeldspraak. In totaal aantal intensiveringen is er geen verschil tussen beide genres.

We gingen vervolgens na of dezelfde patronen zich voordoen bij de intensiveringen die slechts door één codeur zijn geïdentificeerd. De meest frequent gebruikte soorten intensiveringen zijn hier: bijvoeglijke naamwoorden (21.7\%), bijwoorden van modaliteit (12.5\%) en werkwoorden (11.5\%). De versteende beeldspraak was hier net iets minder frequent $(9.7 \%)$. Het blijkt dat opnieuw de bijwoorden van graad, de bijvoeglijke naamwoorden en de versteende beeldspraak verantwoordelijk zijn voor een significant verschil tussen beide genres 
$\left(\right.$ resp. $\chi^{2}(16)=39.36, p<.001$ voor codeur 1 en $\chi^{2}(16)=54.07, p<.001$ voor codeur 2 ; missing value zorgt voor de extra vrijheidsgraad). In hoofdredactionele commentaren werd net als in de hoofdanalyse - vaker gebruik gemaakt van intensiverende bijwoorden van graad en versteende beeldspraak; in recensies werd vaker gebruik gemakt van intensiverende bijvoeglijke naamwoorden. Daarnaast vond codeur 1 meer intensiverende werkwoorden in recensies dan in commentaren. Codeur 2 vond meer intensiverende bijwoorden van modaliteit in hoofdredactionele commentaren dan in recensies, terwijl recensies volgens codeur 2 meer originele beeldspraak bevatten dan commentaren.

2.3 Conclusie deelonderzoek 1 De eerste conclusie moet zijn dat het nieuwe analysesche$\mathrm{ma}$ ons niet in staat stelt tot een voldoende betrouwbare identificatie van intensiverende elementen in de onderzochte genres. De categorisering van intensiverende elementen kan wél met een bevredigende mate van betrouwbaarheid plaats vinden, zeker als een feedbackronde wordt ingebouwd. Het zelfde geldt overigens voor de analyseschema's van Renkema (1997) en Pander Maat (2004). Op het punt van betrouwbaarheid hebben we geen vooruitgang geboekt ten opzichte van hun voorstellen. Op de geringe betrouwbaarheid van de identificatie van intensiverende elementen gaan we in de discussie aan het eind van dit artikel dieper in.

Op basis van de door twee codeurs geïdentificeerde intensiveringen kunnen we vaststellen dat het totale aantal intensiveringen in hoofdredactionele commentaren en recensies geen verschil laat zien. Van Mulken en Schellens (2006) vonden wel een dergelijk verschil: in recensies vonden zij meer intensiveringen dan in commentaren. Dat verschil in totale frequenties lijkt hier plaats te maken voor een andere verdeling over verschillende typen intensivering.

In hoofdredactionele commentaren wordt vaker gebruik gemaakt van bijwoorden van graad en van versteende beeldspraak dan in recensies. Bijwoorden van graad zijn in feite de meest expliciete versterkers die onze taal kent: het zijn de puur lexicale versterkers die geen enkele andere functie hebben. Het zijn eerlijke intensiveringen. Het is niet onvoorstelbaar dat in hoofdredactionele commentaren deze versterkers gelden als een evidente versterking, waar ze in recensies eerder zullen overkomen als een zwaktebod: van de recensent mag verwacht worden dat hij zijn evaluatie eleganter onder woorden brengt. Onderstaand voorbeeld illustreert het gebruik van bijwoorden van graad in commentaren.

(5) $\mathrm{Nu}$ is een debat over die idealen en uitgangspunten [van de EU] zonder meer zinvol. Maar het getuigt wel van erg veel optimisme om te menen dat ... (de Volkskrant 1312-2007)

Hoofdredactionele commentaren maken ook meer gebruik van versteende beeldspraak. Ook dat verbaast ons niet, omdat dit immers uitdrukkingen zijn waarvan de oorspronkelijke versterkende betekenis in de loop der tijd of door het vele gebruik afgesleten is, waardoor de versterkende betekenis - hoogstwaarschijnlijk ontstaan door de combinatie van pregnantie en beeldendheid van de oorspronkelijke vergelijking - niet meer het meest in het oog springende effect van de woordcombinatie is. De volgende voorbeelden illustreren de versteende beeldspraak. 


\section{Over loodzware bassen en wapperende broekspijpen}

(6) Het gevoel dat Nederland de kastanjes uit het vuur moet halen, is dan ook te begrijpen. (de Volkskrant 20-12-2007)

(7) Door de opmars van de Islam is de gevoeligheid voor religieuze scherpslijperij weer sterk toegenomen. (de Volkskrant 12-12-2007)

Recensies doen vaker een beroep op intensiverende voorvoegsels en bijvoeglijke naamwoorden. Ook dat kunnen we begrijpen. Voorvoegsels en bijvoeglijke naamwoorden kleuren op een aansprekende manier de intensiteit van een uiting. In hoofdredactionele commentaren lijken ze ongepast, omdat ze de mening van de auteur te nadrukkelijk laten doorschemeren, in recensies zijn ze juist zeer op hun plaats.

(8) [...] waardoor de film razendsnel aankomt (Bas Blokker, NRC Handelsblad 12-122007)

(9) [...] loodzware bassen (Sasja Kooistra, de Volkskrant 17-12-2007)

(10) [...] een gelikte film (Bas Blokker, NRC Handelsblad 12-12-2007)

(11) De nieuwste roman van Robert Anker, Nieuw-Lelievelt, begint als een oubollig meisjesboek. (Edith Koenders, de Volkskrant 14-12-2007)

Omdat van recensenten verwacht wordt dat ze een kunstuiting evalueren, en dat ze excelleren in het formuleren en motiveren van die mening, ligt het ook in de lijn der verwachting dat vaker gebruik wordt gemaakt van originele beeldspraak in recensies.

(12) Wongs (tijdelijke) verhuizing van Hong Kong naar Amerika is als een scheikundeproef die geen enkel effect in het buisje teweeg brengt. (Ronald Ockhuysen, de Volkskrant 1312-2007)

(13) In de grote zaal lieten harde bassen je broekspijpen wapperen. (Sasja Kooistra, de Volkskrant 17-12-2007)

(14) Zijn onuitgesprokenheid is onder auspiciën van producent Harvey Weinstein verworden tot een plaatjesboek vol uitroeptekens. (Ronald Ockhuysen, de Volkskrant 1312-2007)

We constateren dus dat het analysemodel ons in staat stelt verschillen tussen de genres op te sporen, indien we ons beperken tot de intensiveerders waarover de codeurs overeenstemming bereikten. Geruststellend is bovendien dat deze verschillen goeddeels overeind blijven als we alleen kijken naar de intensiveringen die slechts door één codeur zijn geïdentificeerd. Verder onderzoek naar verschillen tussen genres ligt voor de hand. Maar er is ook onderzoek mogelijk naar verschillen tussen bijvoorbeeld: kranten (De Telegraaf versus de door ons onderzochte kranten), kanalen (kranten versus websites) of sprekers (Tweede Kamerleden van oppositiepartijen versus regeringspartijen). 
Om misverstanden te voorkomen: ons analysemodel impliceert niet dat de onderscheiden categorieën per definitie intensiverend zijn. Dat geldt mogelijk alleen voor de bijwoorden van graad, die versterking - hoe zwak soms ook - als enige functie hebben. Een bijvoeglijk naamwoord is nooit per definitie intensiverend. De codeur moet bij een bijvoeglijk naamwoord dat hij als een mogelijke intensivering ziet, nagaan of het in de context weggelaten of vervangen kan worden met een zwakkere uiting als resultaat. Hetzelfde geldt voor alle overige categorieën. Daardoor blijft het voor codeurs kennelijk een lastige opgave intensiveringen in teksten aan te wijzen.

Dat roept de vraag op of intensiveringen in het dagelijkse taalgebruik wellicht ook onopgemerkt blijven door de recipiënten. Mocht dat zo zijn dan mag van een dergelijk stilistisch verschijnsel natuurlijk ook niet al te veel effect worden verwacht op de overtuigingskracht van persuasieve teksten. Om die reden gaan we in het tweede deelonderzoek in op de perceptie van intensiveringen door gewone taalgebruikers: zien zij een verschil in intensiteit en subjectiviteit tussen teksten met en zonder intensivering?

Er zijn twee deelexperimenten uitgevoerd, waarbij het ene deelexperiment weglaatbare intensiveerders onder de loep nam, het andere deelexperiment vervangbare intensiveerders. Om de deelexperimenten aan elkaar te kunnen linken zijn vier stimuli uit het eerste deelexperiment op exact dezelfde wijze gebruikt in het tweede deelexperiment (namelijk weglaatbare bijvoeglijke naamwoorden).

\subsection{Methode}

\section{Materiaal}

Er zijn in totaal 40 tekststimuli van elk drie of vier regels ontwikkeld, in telkens twee condities. De laatste zin bevatte in de ene versie een intensiveerder en in de andere versie niet. In de geïntensiveerde conditie werd gebruik gemakt van 10 verschillende categorieën intensiveringen: bijwoorden (bijwoorden van graad, bijwoorden van frequentie of kwantiteit, bijwoorden van modaliteit en adverbiaal gebruikte bijvoeglijke naamwoorden), bijvoeglijke naamwoorden (weglaatbaar en vervangbaar), zelfstandig naamwoorden, werkwoorden en beeldspraak (versteend en origineel). Onderstaande voorbeelden (15) en (16) illustreren items waarbij een bijwoord van modaliteit (natuurlijk) en een bijvoeglijk naamwoord (voortreffelijke) is gebruikt. De tegenhanger van deze variant bevat de intensiveerder niet: hij kon worden weggelaten, zoals in (15) of werd vervangen door een zwakkere formulering zoals in (16). ${ }^{7}$

(15) Volgens de docent heeft een aantal deelnemers aan de cursus de uitwerkingen van de opdrachten gekopieerd van ouderejaars. Een aantal andere studenten hebben hun eigen antwoorden erop gebaseerd. De docent meldt dat dat natuurlijk niet de bedoeling is. 


\section{Over loodzware bassen en wapperende broekspijpen}

(16) In diverse dagbladen werden goede recensies geschreven over restaurant De Kei in Valkenswaard. Het restaurant kent een gemoedelijke sfeer en is rustig gelegen. Volgens de recensent van het Algemeen Dagblad serveert het restaurant met name voortreffelijke (> lekkere) visgerechten.

De ervaren mate van subjectiviteit werd als volgt geoperationaliseerd: deelnemers werden geconfronteerd met een stelling ("De mening van de docent klinkt door in de tekst") en moesten op een zevenpunts Likert-schaal aangeven in hoeverre ze het met de stelling eens of oneens waren. Bij andere items werd 'de docent' vervangen door de relevante spreker in het betreffende tekstje. De ervaren mate van intensiteit werd eveneens gemeten met behulp van een stelling ('De laatste zin is sterker dan neutraal') en een zevenpunts Likert-schaal.

\section{Deelnemers}

In totaal deden 120 proefpersonen mee aan het experiment, 60 an elk van beide deelexperimenten. Het waren allen bèta-studenten aan de Radboud Universiteit Nijmegen, variërend in leeftijd van 17 tot 26 jaar (gemiddeld 21,3 jaar). Er waren 66 mannelijke en 54 vrouwelijke participanten. Alle proefpersonen hadden Nederlands als moedertaal. De proefpersonen ontvingen geen vergoeding voor hun medewerking.

Design

De eerste groep deelnemers beoordeelde weglaatbare intensiveerders in tekstjes met intensiverende bijwoorden en weglaatbare bijvoeglijke naamwoorden, de andere groep deelnemers beoordeelde vervangbare intensiveerders, in de categorieën intensiverende bijvoeglijke naamwoorden, zelfstandige naamwoorden, werkwoorden en versteende en originele beeldspraak. Bovendien werden in het tweede deelexperiment ook de tekstjes met weglaatbare bijvoeglijke naamwoorden aan de deelnemers voorgelegd.Van de 20 respectievelijk 24 tekstjes die een participant te zien kreeg, bevatten de helft wel een intensiveerder en de helft geen intensiveerder. De tien verschillende categorieën intensiveerders kwamen elk in vier van de veertig teksten voor. Elke participant beoordeelde dus twee representanten van elk type intensiveerder. De andere twee teksten die voor datzelfde type intensiveerder waren geconstrueerd kreeg de participant te zien zonder intensiveerder. Om te controleren voor volgorde- en vermoeidheidseffecten zijn in totaal per groep vier lijsten gemaakt. 


\subsection{Resultaten}

De gemiddelde scores van gepercipieerde subjectiviteit en intensiteit staan in Tabel 2.

Tabel 2: Gemiddelde gepercipieerde subjectiviteit en kracht (en standaard deviatie), per categorie intensiveerder $(1=$ laag, $7=$ hoog), in de condities afwezig en aanwezig

\begin{tabular}{|c|c|c|c|}
\hline Soort intensivering & & subjectiviteit & intensiteit \\
\hline \multirow[t]{2}{*}{ Bijwoord van graad } & Wel aanwezig & $5.32(1.38)$ & $4.68(1.19)$ \\
\hline & Niet aanwezig & $5.05(1.28)$ & $4.10(1.46)^{\star \star}$ \\
\hline \multirow{2}{*}{$\begin{array}{l}\text { Bijwoord van frequentie } \\
\text { of kwantiteit }\end{array}$} & Wel aanwezig & $4.70(1.25)$ & $4.25(1.36)$ \\
\hline & Niet aanwezig & $4.26(1.11)^{\star}$ & $3.62(1.29)^{\star \star}$ \\
\hline \multirow[t]{2}{*}{ Bijwoord van modaliteit } & Wel aanwezig & $4.83(1.30)$ & $4.46(1.38)$ \\
\hline & Niet aanwezig & $3.81(1.38)^{\star \star}$ & $3.74(1.44)^{\star \star}$ \\
\hline Adverbiaal gebruikt & Wel aanwezig & $4.25(1.37)$ & $4.53(1.22)$ \\
\hline bijvoeglijk naamwoord & Niet aanwezig & $3.43(.96)^{\star \star}$ & $3.23(1.13)^{\star \star}$ \\
\hline \multirow[t]{2}{*}{ Weglaatbaar bijvoeglijk naamwoord\# } & Wel aanwezig & $4.20(1.57)$ & $4.16(1.33)$ \\
\hline & Niet aanwezig & $3.56(1.44)^{\star \star}$ & $3.00(1.25)^{\star \star}$ \\
\hline \multirow[t]{2}{*}{ Vervangbaar bijvoeglijk naamwoord } & Wel aanwezig & $4.77(1.33)$ & $4.73(1.19)$ \\
\hline & Niet aanwezig & $4.22(1.36)^{\star \star}$ & $3.46(1.25)^{\star \star}$ \\
\hline \multirow[t]{2}{*}{ Werkwoord } & Wel aanwezig & $3.09(1.25)$ & $3.97(.97)$ \\
\hline & Niet aanwezig & $2.68(1.41)+$ & $2.89(1.16)^{\star \star}$ \\
\hline \multirow[t]{2}{*}{ Zelfstandig naamwoord } & Wel aanwezig & $5.53(1.06)$ & $5.14(1.34)$ \\
\hline & Niet aanwezig & $4.81(1.32)^{\star \star}$ & $4.11(1.16)^{\star \star}$ \\
\hline \multirow[t]{2}{*}{ Originele beeldspraak } & Wel aanwezig & $4.77(1.07)$ & $5.21(1.11)$ \\
\hline & Niet aanwezig & $4.76(1.18)$ & $3.96(1.24)^{\star \star}$ \\
\hline \multirow[t]{2}{*}{ Versteende beeldspraak } & Wel aanwezig & $5.65(.97)$ & $5.37(1.02)$ \\
\hline & Niet aanwezig & $5.28(1.05)^{\star}$ & $3.95(1.16)^{\star \star}$ \\
\hline \multirow[t]{2}{*}{ Totaal } & Wel aanwezig & $4.62(.76)$ & $4.57(.80)$ \\
\hline & Niet aanwezig & $4.07(.66)^{\star \star}$ & $3.59(.78) \star \star$ \\
\hline
\end{tabular}

$\star=$ verschil tussen conditie met en conditie zonder intensiveerder is significant, $\mathrm{p}<.05$

$\star \star=\mathrm{p}<.01$

$+=\mathrm{p}=.06$

\#Omdat deze deelset van stimuli (weglaatbare bijvoeglijke naamwoorden) in beide deelexperimenten is gebruikt, is dit gemiddelde berekend over 120 proefpersonen, en niet over 60 .

Bezien we alle categorieën samen, dan blijkt er een significant verschil tussen de tekstjes mét en zonder intensivering. De tekstversies met intensivering worden als krachtiger gepercipieerd dan de versies zonder intensivering $(\mathrm{t}(119)=12.59, \mathrm{p}<.001)$. Er is ook een significant overall verschil in gepercipieerde subjectiviteit: de tekstjes met intensivering worden als subjectiever gepercipieerd dan de tekstjes zonder intensivering $(\mathrm{t}(119)=7.37, \mathrm{p}<.001)$.

Als we de categorieën afzonderlijk beschouwen, dan blijkt de ervaren mate van inten- 


\section{Over loodzware bassen en wapperende broekspijpen}

siteit bij tekstjes met intensiveerder voor alle categorieën significant hoger dan bij teksten zonder die intensiveerders. Datzelfde geldt niet voor de ervaren mate van subjectiviteit. De intensiverende bijwoorden van graad, werkwoorden en originele beeldspraak blijken geen verschil in ervaren subjectiviteit op te leveren (hoewel de intensiverende werkwoorden bijna significant scoorden). In teksten met de andere categorieën klonk naar de mening van de deelnemers vaker de mening van de geciteerde bron door dan wanneer deze intensiveerder ontbrak.

3.3 Conclusie deelonderzoek 2 Voor alle categorieën taalintensiveerders vonden we een toename in gepercipieerde kracht als de intensiveerder in kwestie in de laatste zin stond van de door de deelnemers beoordeelde teksten. Dat is uiteraard ook wat we verwachtten. We zien echter ook dat zes van de tien typen taalintensiveerders meer doen dan dat: bijwoorden van frequentie of kwantiteit, bijwoorden van modaliteit, adverbiaal gebruikte bijvoeglijk naamwoorden, weglaatbare bijvoeglijke naamwoorden, zelfstandige naamwoorden en versteende beeldspraak kleuren de uiting doordat ze de mening van de geciteerde bronmeer laten doorklinken dan tekstjes zonder die intensiveringen. Intensiverende bijwoorden van graad, adverbiaal gebruikte bijvoeglijke naamwoorden, originele beeldspraak en werkwoorden doen dat niet, volgens onze proefpersonen. In het geval van de originele beeldspraak was de ervaren subjectiviteit überhaupt erg hoog, in het geval van de werkwoorden constateren we een trend in dezelfde richting als bij de andere intensiveerders. Kortom, in veel gevallen doen intensiveerders meer dan alleen intensiveren, ze maken een evaluatieve uiting in de perceptie van onze proefpersonen ook subjectiever dan de evaluaties zonder intensivering. 'Een fantastisch mooi boek' wordt subjectiever gevonden dan 'een mooi boek'.

\section{Discussie}

In deelonderzoek 1 vonden we een aantal verschillen tussen intensiveringen in hoofdredactionele commentaren en recensies: in commentaren wordt meer dan in recensies gebruik gemakt van intensiverende bijwoorden van graad en versteende beeldspraak; in recensies wordt meer dan in commentaren gebruik gemaakt van intensiverende voorvoegsels, bijvoeglijke naamwoorden en originele beeldspraak. Deze resultaten zijn gebaseerd op de intensiveringen die door beide codeurs onafhankelijk van elkaar werden vastgesteld. In de analyse van intensiveringen die slechts door één codeur werden geïdentificeerd, bleken dezelfde verschillen op te treden voor bijwoorden van graad, versteende beeldspraak en bijvoeglijke naamwoorden. De categorisering van intensiveringen bleek met een matige/redelijke betrouwbaarheid te kunnen worden uitgevoerd. Het grootste probleem blijft een betrouwbare identificatie van intensiveerders. Slechts $33 \%$ van het totaal aantal gevonden intensiveringen werd door beide codeurs onafhankelijk van elkaar aangewezen.

In deelonderzoek 2 werden uitingen mét intensiveerder door de proefpersonen steeds krachtiger en meestal subjectiever gevonden dan uitingen zonder intensiveringen. De gepercipieerde kracht nam door het gebruik intensiveringen uit alle afzonderlijke categorieën toe.

Het lijkt erop dat onze proefpersonen er beter in slagen taalintensiteit te herkennen dan wij, als codeurs. Hoe valt dit te verklaren? Allereerst hebben we in het experimentele materiaal natuurlijk zo veel mogelijk gebruik gemaakt van duidelijke gevallen. Bovendien kon in het 
experiment de uiting met een taalintensiveerder naadloos vergeleken kon worden met dezelfde uiting zonder die intensiveerder. In het geval van de corpusanalyse moest een codeur telkens zelf een minder krachtig alternatief voor de uiting met een potentiële intensiveerder construeren, en vervolgens het verschil in intensiteit beoordelen. Onze werkdefinitie bevat de noties 'minder krachtig' en 'relevant', en dat zijn verre van discrete categorieën. De vergelijkingsgrond kon dus per codeur verschillen, en dientengevolge zijn of haar oordeel over de taalintensiveerder.

Wat maakt nu dat het zo moeilijk is overeenstemming te bereiken over de identificatie van taalintensiveerders? Een extreem maar typerend voorbeeld van de verschillen in benadering tussen de beide codeurs biedt dit voorbeeld (17):

Er zitten niettemin nog wat adders onder het gras. Ten eerste is het politieke profiel van Medvedev zo goed als nihil.Voordat hij eind 2005 werd benoemd tot vicepremier, was hij hoofd van de presidentiële administratie. Dat is weliswaar een machtsapparaat zonder weerga, maar Medvedev is toch eerder een bureaucraat dan een politicus. Het is de vraag welke compensatie de welhaast xenofobe nationalisten en siloviki, die zich ideologisch nadrukkelijk roeren, nu zullen eisen. (NRC Handelsblad 11-12-2007)

De ene codeur markeerde de volgende elementen als intensiverend: adders onder het gras;

zo goed als; welhaast; xenofobe; zich roeren. De andere codeur noteerde de volgende gevallen: niettemin; nihil; zonder weerga; eerder; welhaast; nadrukkelijk.

Wat we zien is dat de codeurs elkaar op wonderlijke wijze aanvullen. Waar de een een intensiveerder ziet in zo goed als ziet de ander dat in nihil, waar de een een intensiveerder ziet in zich roeren, ziet de ander dat in nadrukkelijk. Beiden ervoeren de intensiteit van een passage, maar schreven die aan verschillende taalelementen toe. Mogelijk schuilt het probleem dus niet zozeer in de perceptie van de kracht van een uiting, maar in de toewijzing van die kracht aan individuele taalelementen. Martin en White (2005) beschouwen de kracht van een uiting en de up scaling en down scalinger van daarom als een 'prosodisch' verschijnsel: net als bij prosodie (volume, toonhoogte) kan de kracht van een uiting niet of moeilijk worden toegeschreven aan discrete elementen, maar komt deze cumulatief tot stand in een opeenvolging van woorden. Dat gaat ons wat ver, maar we stellen vast dat er niettemin gemakkelijk overcodering, ondercodering of uiteenlopende interpretatie van intensiverende elementen kan optreden.

Van overcodering is sprake als de onderscheiden categorieën van intensiverende elementen de codeur verleiden tot een te snel oordeel. Een bijwoord van kwantiteit of versteende beeldspraak kán intensiverend zijn, maar niet elk bijwoord of élke versteende beeldspraak is dat ook daadwerkelijk. Zijn de adders onder het gras een vorm van informeel taalgebruik of versterken ze ook? Niettemin is een minder frequent verbindingswoord dan echter, maar is het ook krachtiger?

Van ondercodering is sprake wanneer intensiveringen over het hoofd worden gezien. Dat kan zich gemakkelijk voordoen in passages waarin de dichtheid van intensiveringen groot is en krachtige intensiveringen worden overschaduwd door minder krachtige. De wat subtielere intensiveringen (zo goed als nihil) blijven dan gemakkelijk onopgemerkt.

Van interpretatieverschillen is ten slotte sprake, als de ene codeur een element anders opvat dan de andere. Versterkt het adjectief xenofobe de kwalificatie nationalisten, dan zijn xenofobe nationalisten dus in de ogen van de codeur meer nationalist dan 'gewone' nationalisten 


\section{Over loodzware bassen en wapperende broekspijpen}

en wordt daarmee de (impliciet gelaten) negatieve evaluatie van de aangeduide groep ondersteund. Als het adjectief xenofobe echter een eigenschap toeschrijft aan nationalisten, die niet al deel uitmaakt van de betekenis van het substantief nationalist, dan is er geen sprake van versterking. Als zich roeren wordt geïnterpreteerd als een synoniem voor van zich laten horen, is er geen sprake van intensivering. Als de codeur zich roeren echter leest als zich verzetten, in opstand komen, dan kan dit - in de afwezigheid van een feitelijke opstand - als een versterkende hyperbool worden opgevat.

Over- en ondercodering en verschil in interpretatie lijken de belangrijkste redenen te zijn waarom de codeurs het oneens waren. Over- en ondercodering zijn eenvoudigweg te beschouwen als een codeerfout, en kunnen niet toegeschreven worden aan een fout in het analysemodel. Verschil van mening over de interpretatie is echter geen codeerfout; het impliceert dat het analysemodel intrinsiek ambigu is.

Met dergelijke fouten willen we het liefst afrekenen. Maar de vraag is of dat mogelijk is. Is het überhaupt mogelijk om een hoge mate van overeenstemming te bereiken in het geval van stilistische tekstkenmerken, zoals taalintensiteit? Spooren en Degand (2010) bespreken vergelijkbare codeerdilemma's bij de benoeming van coherentierelaties. Bij de analyse van coherentierelaties in een deelcorpus van het corpus Gesproken Nederlands, bleek het onmogelijk om de vereiste standaard, een kappascore van .80 of hoger te bereiken. Ondanks herhaalde bijstellingen en verfijningen van het codeboek bleef de kappa steken op .60. Spooren en Degand schrijven deze onmogelijkheid mede toe aan het wezen van het onderzoeksobject: stilistische middelen zijn in essentie redundant en ambigu. De interpretatie van de onderzoekseenheden hangt af van de context en die is nu eenmaal voor elke lezer anders. 'Low kappa's are a fact of life' verzuchten Spooren en Degand dan ook. Zij stellen daarom voor dat de gebruikelijke standaard van een kappa van .80 voor stilistisch onderzoek bijgesteld wordt naar .70. Bijna perfecte overeenstemming is in het geval van interpretatieve ambiguïteit nu eenmaal onmogelijk. Ze stellen bovendien voor om in stilistisch onderzoek te opteren voor de gezamenlijke analyse van het gehele corpus door beide codeurs en niet, zoals gebruikelijk is in geval van een analyse met discretere analyse-eenheden, slechts 15 of $20 \%$ van het totale corpus door twee codeurs te laten analyseren (Neuendorf, 2002). Onenigheid zou dan kunnen worden opgelost in discussie. Wij kozen er ook voor om het gehele corpus door twee codeurs te laten analyseren. We zagen echter af van de schier oneindige reeks discussies (ongeveer 500 gevallen), en opteerden voor een werkbaarder oplossing: we beschouwden de individuele analyses van de codeurs als convergerende verzamelingen, en onderzochten of de doorsnede van die verzamelingen systematisch afweek van de individuele verzamelingen. De ontwikkeling van een adequate statistische toets voor de mate van convergentie tussen de doorsnede en de individuele analyses is dan ook zeer gewenst: dit zou de validiteit van ons analysemodel zeker ondersteunen, omdat deze toets een indicatie van het aandeel 'codeerfouten' kan geven, zonder afbreuk te doen aan de intrinsieke ambiguïteit van het fenomeen.

Spooren en Degand (2010) wijzen bovendien op een 'onrechtvaardigheid' die eigen is aan het berekenen van de Cohen's kappa. Inherent aan de berekeningswijze van Cohen's kappa is dat de kappa altijd lager uitvalt indien er sprake is van een grote hoeveelheid categorieën (zoals in ons geval: 17 categorieën) en de categorieën niet noodzakelijk evenredig verdeeld zijn over het corpus (syntactische intensiveringen komen bijvoorbeeld aanzienlijk minder vaak voor dan intensiverende bijvoeglijk naamwoorden). ${ }^{9}$ Artsein en Poesio (2008) wijzen op nog een ander nadeel van de berekeningswijze van Cohen's kappa: categoriedominantie. Er is sprake van categoriedominantie als een bepaalde categorie disproportioneel 
vaak voorkomt. Ook dan pleegt Cohen's kappa lager uit de vallen. Dit speelt ook een rol in ons onderzoek: de kappa's die we hier rapporteerden zijn gebaseerd op de totale set aan intensiveerders die een of twee codeurs in het corpus identificeerden. Wat niet meegenomen is, in de berekening van deze kappa, zijn alle gevallen waarin naar de mening van beide codeurs geen intensiveerder voorkwam: deze categorie zou dan ook in onze dataset ver uit dominant zijn. Gezien het feit dat ons totale corpus bestond uit 13.640 woorden en gezien het feit dat door een of twee codeurs in totaal slechts een kleine 750 intensiverende eenheden zijn aangemerkt, hadden we de categorie 'geen taalintensiteit' in ons analyseschema kunnen opnemen. Ondanks dat we het dus vaak eens waren over het feit dat een woord of uiting geen taalintensiveerder bevatte, zou de opname van deze categorie een nog lagere kappa hebben opgeleverd.

Als we 'geen taalintensiteit' hadden meegenomen als categorie, hadden we voor een andere wijze van berekening van overeenstemming kunnen kiezen. Feinstein en Cichetti (1990), stellen net als Artsein en Poesio de 'paradox van Cohen' aan de orde en bepleiten dat per categorie gerapporteerd wordt hoe vaak (welk percentage) codeurs wel en hoe vaak (welk percentage) codeurs niet opteerden voor een bepaalde categorie (positive and negative agreement) (zie ook Burgers, 2010). We hadden dan glorieus kunnen concluderen dat de codeurs het kennelijk in ongeveer $93 \%$ van de gevallen met elkaar eens waren (alle gevallen waarin geen van de codeurs een taalintensiveerder noteerde). We hebben desalniettemin niet gekozen voor deze wijze van rapporteren, omdat de statistische houdbaarheid van deze analyse twijfelachtig is (er wordt geen rekening gehouden met de op basis van kans verwachte aantallen - zie Carletta 1996).

Kortom, er kleven systematische problemen aan de identificatie van stilistische grootheden, die wij in deze bijdrage niet eenduidig hebben kunnen oplossen. Ons analysemodel (TIM) stelde de codeurs in staat gevallen van taalintensiteit in een tekst aan te wijzen en te benoemen. We stellen vast dat de analysemethode niet betrouwbaar genoeg is om met voldoende zekerheid individuele intensiveringen te localiseren, maar het model stelde de codeurs wél in staat om onafhankelijk van elkaar een verschil tussen twee genres vast te stellen. Kennelijk is het model robuust genoeg om patronen en systematiek in de verschillen tussen tekstgenres te onderscheiden. Dat is een merkwaardige paradox, die erop wijst dat de eisen die we aan de betrouwbaarheid van een meetinstrument stellen, gerelateerd zouden moeten worden aan het object van onderzoek en aan de vraagstelling in het onderzoek.

Hoewel de identificatie van intensiverende middelen in analytisch onderzoek nog voor problemen zorgt, willen we in vervolgonderzoek graag meer licht werpen op het gebruik van intensiveringen in uiteenlopende genres. Vervolgens keren we terug naar de vraag uit de inleiding van dit artikel: wanneer dragen intensiveringen bij aan de overtuigingskracht van teksten? En doen ze dat in verschillende genres op dezelfde manier? Op grond van de inventarisatie van intensiverende stijlmiddelen in ons model zijn zorgvuldiger manipulaties van tekstmateriaal mogelijk dan in experimenteel onderzoek tot nu toe gebruikelijk is. Hopelijk krijgen we daardoor beter zicht op de functie en de overtuigingskracht van taalintensiverende stijlmiddelen. 


\section{Over loodzware bassen en wapperende broekspijpen}

\section{Noten}

* We danken Lettica Hustinx en Christine Liebrecht, alsmede twee anonieme reviewers voor hun zinvolle commentaar op een eerdere versie van dit artikel. Het onderzoek kwam tot stand dankzij de inspanningen van een aantal studenten Nederlandse taal en cultuur: Kim Bogers, Joske Duifhuizen, Christine Liebrecht, Yvette Linders, Jet Meerkerk, Marloes Musters en Laurent Spijker.

1 Onze definitie bouwt voort op die van Renkema (1997, p. 497) en Pander Maat (2004, p. 210). Ook zij koppelen intensivering aan de mogelijkheid een zwakker alternatief te formuleren. Anders dan Renkema koppelen wij intensivering uitdrukkelijk aan evaluatieve uitingen. Dat doet Pander Maat vermoedelijk ook door zijn link met de argumentatieve kracht in de zin van Ducrot (1980). Die link gaat ons echter te ver; hij heeft o.m. als consequentie dat bij Pander Maat ook een afzwakker kan versterken (verzwakkingen van negatief gewaardeerde getallen, bijvoorbeeld 'een verlies van slechts 10 miljoen'). Dat het zwakkere alternatief grammaticaal correct moet zijn ontlenen we aan Pander Maat.

2 Renkema reserveert de term stilistisch voor de intensiveringen door middel van een stijlfiguur. Wij zouden de lexicale en semantische intensiveringen ook stilistisch van aard noemen.

3 Het analyseschema en de instructie werd in een eerste versie ontwikkeld in een doctoraal werkgroep Nederlandse taal en cultuur onder leiding van de tweede auteur, bestaande uit Joske Duifhuizen, Christine Liebrecht, Yvette Linders, Jet Meerkerk en Laurent Spijker, en later licht bijgesteld door Kim Bogers (2008).

4 Het onderzoek werd opgezet en uitgevoerd door masterstudente Nederlandse taal en cultuur Kim Bogers (Bogers, 2008). De beide codeurs waren dezelfde als in het onderzoek van Van Mulken en Schellens (2006), namelijk de beide auteurs van dit artikel.

5 De keuzemogelijkheden werden in de instructie als volgt omschreven:

$1=\mathrm{ik}$ blijf bij mijn eerste categorisering, want deze vind ik beter dan die van de andere beoordelaar.

$2=\mathrm{ik}$ ben van mening veranderd en vind dat mijn eerste categorisering minder goed is dan die van de andere beoordelaar.

3 = ik vind beide opties even goed, ik zou me er ook in kunnen vinden als we uiteindelijk kiezen voor de categorisering van de andere beoordelaar.

$4=\mathrm{ik}$ heb gekozen voor een andere categorisering dan onze beide eerste categoriseringen, omdat ik deze in tweede instantie toch beter vind. Let op: dit komt zelden voor!

6 Een van de anonieme reviewers wees terecht op het grote aantal cellen met lage aantallen, en suggereerde om onderzoekseenheden samen te nemen voor de berekening van de chi-kwadraat. Omdat dat zou leiden tot hybride categorieën hebben we daar niet voor gekozen. Wel hebben we de analyse uitgevoerd op dezelfde dataset waarbij de minst frequente categorieën zijn samengenomen in de categorie 'overig' (de stijlfiguren, de syntactische intensiveringen en de typografische). Opnieuw was het verschil tussen de genres significant $\left(\mathrm{X}^{2}(11)=\right.$ $24.52, \mathrm{p}<.01)$.

7 Deelonderzoek 2 is in twee deelexperimenten met eenzelfde design uitgevoerd doorYvette Linders en Marloes Musters (Linders 2007, Musters 2009). We voegen de resultaten van die twee experimenten hier samen.

8 In het experimentele materiaal werden de volgende intensiveerders gebruikt. Bijwoorden van graad: bij uitstek, hoogst, volstrekt, erg; bijwoorden van frequentie of kwantiteit: ruim, altijd, immer, al te vaak; bijwoorden van modaliteit: terecht, wat al te, natuurlijk, uiteraard; adverbiaal gebruikte bijvoeglijke naamwoorden: verdomd, fors, radicaal, overtuigend; weglaatbare bijvoeglijke naamwoorden: massale, uitgelezen, toonaangevend, forse; vervangbare bijvoeglijke naamwoorden: fantastische ( $>$ goede), voortreffelijke $(>$ lekkere), huiveringwekkende ( $>$ angstige), euforisch ( $>$ goed); werkwoorden: kelderde $(>$ daalde), gesmeten ( $>$ gegooid), commandeerden ( $>$ instrueerden), scheuren ( $>$ rijden); zelfstandige naamwoorden: triomf ( $>$ succes), fascinatie ( $>$ interesse), ramp ( $>$ problemen), blamage ( $>$ minpunt); originele beeldspraak: net een bungalowtent $(>$ te groot), dekking 
gezocht tijdens de drumsolo ( $>$ te harde drumsolo); exploderende ( $>$ stijgende), slappe koffie ( $>$ geen sterk voorstel); versteende beeldspraak: als kippen zonder kop ( $>$ zonder na te denken), het schip in gaan $(>$ verlies lijden), een dijk van een voorstel ( $>$ een goed voorstel), op de schop moeten ( $>$ aangepast moeten worden). Overigens bestaat er een alternatief voor dit soort gevallen: de 'gewogen kappa'. De variabelen moeten dan echter ordinaal zijn (Wilson et al. 2006).

$9 \quad[\ldots]$ loodzware bassen (Sasja Kooistra, de Volkskrant 17-12-2007)

\section{Bibliografie}

Artsein, R., \& Poesio, M. (2008). Inter-coder agreement for computational linguistics. Computational Linguistics, 34 , 555-596.

Bogers, K. (2008). 'Een schril contrast: exploderende directiesalarissen en uitgeklede dienstverlening'. Een onderzoek naar taalintensiteit in recensies en hoofdredactionele commentaren. Masterscriptie Nederlandse taal en cultuur, Radboud Universiteit Nijmegen.

Bowers, J.W. (1963). Language intensity, social introversion, and attitude change. Speech Monographs, 30, 345-352.

Buller, D.B., Burgoon, M., Hall, J.R., Levine, N., Taylor, A.M., Beach, et. al. (2000a). Long-term effects of language intensity in preventive messages on planned family solar protection. Health Communication, 12, 261-275.

Buller, D.B., Burgoon, M., Hall, J.R., Levine, N., Taylor, A.M., Beach, et al. (2000b). Using language intensity to increase the success of a family intervention to protect children from ultraviolet radiation. Predictions from language expectancy theory. Preventive Medicine, 30, 103-114.

Burgers, C. (2010). Verbal irony: Use and effects in written discourse. Proefschrift Radboud Universiteit Nijmegen.

Carletta, J. (1996). Assessing agreement on classification tasks: The kappa statistic. Computational Linguistics, 22, 249254.

Ducrot, O. (1980). Les echelles argumentatives. Paris: Les Editions de Minuit.

Feinstein, A.R., \& Cicchetti, D.V. (1990). High agreement but low kappa: I. The problems of two paradoxes. Journal for Clinical Epidemiology, 43, 543-549.

Haeseryn, W., Romijn, K., Geerts, G., Rooy, J. de, \& Toorn, M.C. van den (1997). Algemene Nederlandse Spraakkunst. Groningen: Martinus Nijhoff.

Hamilton, M.A., \& Hunter, J.E. (1998). The effect of language intensity on receiver evaluations of message, source, and topic. In M. Allan \& R.W. Preiss (Red.). Persuasion:Advances through meta-analysis (pp. 99-138). Creskill NJ: Hampton Press.

Hamilton, M.A., Hunter, J.E., \& Burgoon, M. (1990). An empirical test of an axiomatic model of the relationship between language intensity and persuasion. Journal of Language and Social Psychology, 9, 235-255.

Hornikx, J., Pieper, M., \& Schellens, P.J. (2008). Versterkende, afzwakkende en numerieke markeringen in claims over cosmeticaproducten. Maken ze claims overtuigender? Tijdschrift voor Communicatiewetenschap, 36, 3-14.

Linders, Y. (2007). Intensiveerders: natuurlijk enorm krachtig. Toetsing van een analyseschema voor intensiveerders en een perceptieonderzoek naar taalintensiteit. Masterscriptie Nederlandse taal en cultuur, Radboud Universiteit Nijmegen.

Martin, J.R., \& White, P.R.R. (2005). The language of evaluation. Appraisal in English. Basingstoke / New York: Palgrave Macmillan

Mathijsen, M. (2007). De afwezigheid van het verleden. Amsterdam: Querido.

Mulken, M. van, \& Schellens, P.J. (2006). Overtuigend? Een stilistische analyse van persuasieve teksten. In H. Hoeken, B. Hendriks \& P.J. Schellens (Red.). Studies in taalbeheersing 2 (pp. 224-236). Assen:Van Gorcum.

Musters, M. (2009). Herkent u dat? Die taalintensiveerders ....? Een perceptieonderzoek naar taalintensiteit. Masterscriptie Nederlandse taal en cultuur, Radboud Universiteit Nijmegen. 


\section{Over loodzware bassen en wapperende broekspijpen}

Neuendorf, K.A. (2002). The content analysis guidebook. Thousand Oaks: Sage.

Pander Maat, H. (2004). Wervend taalgebruik in persberichten - werkt het? Hoe journalisten omgaan met persberichten in de luchtvaartsector. Tijdschrift voor Taalbeheersing, 26, 207-223.

Pander Maat, H. (2007). How promotional language in press releases is dealt with by journalists. Genre mixing or genre conflict? Journal of Business Communication, 44, 59-95.

Renkema, J. (1997). Geïntensiveerd taalgebruik: een analyseschema. In H. van den Bergh, D, Jansen, N. Bertens \& M. Damen (Red.). Taalgebruik ontrafeld (pp. 495-504). Dordrecht: Foris Publications.

Schellens, P.J. (2006). 'Bij vlagen loepzuiver'. Over argumentatie en stijl in betogende teksten. Tijdschrift voor Taalbeheersing, 28, 346-360.

Spooren, W., \& Degand, L. (2010). Coding coherence relations: reliability and validity. Corpus Linguistics \& Linguistic Theory, 6, 241-266.

Wilson, T., Wiebe, J., \& Hwa, R. (2006). Recognizing strong and weak opinion clauses. Computational Intelligence, 22, 73-99. 


\section{Bijlage:}

Taalintensiveringen in persuasieve teksten. Een instructie voor het vaststellen en benoemen.

A. Wanneer is een tekstelement een intensivering?

Onder taalintensiveringen verstaan we alle stilistische middelen die een schrijver kan gebruiken om een uiting kracht bij te zetten.

1. Welke delen van een tekst betrekken we in de analyse?

Buiten beschouwing blijven:

- Titels en (sub)koppen van artikelen

- Letterlijke citaten van anderen dan de auteur

- Redactionele leads

Wel in de analyse te betrekken:

- Parafrases van uitspraken van anderen door de schrijver

- Tekst tussen haakjes of tussen gedachtestrepen

2. Hoe stellen we vast of een tekstelement een intensivering is?

Een tekstelement is een intensivering wanneer het element:

○ kan worden weggelaten of vervangen met als resultaat:

- een minder krachtige uiting

$\circ$ die in de context relevant is

Dit is een schitterend boek

$>$ Dit is een mooi boek

Hij levert een uiterst kritisch commentaar

$>$ Hij levert een kritisch commentaar

In het volgende voorbeeld is mooi geen intensivering

Dit is een mooi boek

$>$ Dit is een boek

(wel correct, maar in de context niet relevant)

\section{LET OP}

Het is soms moeilijk vast te stellen wanneer een element nog vervangbaar is door een zwakker element. Iemand kan vinden dat mooi in bovenstaand voorbeeld te vervangen is door aardig. Maar wordt het positieve oordeel van de recensent sterker ondersteund door mooi dan door aardig? Om deze discussie te vermijden spreken we af dat we een aantal positief waarderende adjectieven als ondergrens opvatten. Dat geldt voor: goed, mooi, aardig, leuk, fijn, grappig, prettig, geschikt en parafrases daarvan met een vergelijkbare intensiteit.

3. Welke tekstelementen komen in aanmerking?

Meestal gaat het om woorden. Daarnaast kan het gaan om:

○ woorddelen, in het geval van intensiverende voorvoegsels

Dat is gloednieuw

$>$ Dat is nieuw

○ woordgroepen, als een aantal woorden samen versterkend werkt, zonder dat het ene woord optreedt als versterker van het andere. Dat kan zich voordoen bij adverbia:

Dat is maar al te waar 


\section{Over loodzware bassen en wapperende broekspijpen}

$>$ Dat is waar

○ bij verbale uitdrukkingen:

Hij ging er vandoor

$>$ Hij vertrok

bij stijlfiguren

Het gaat bergafwaarts met het onderwijs

$>$ Het gaat steeds slechter met het onderwijs

Wanneer in een woordgroep wel kan worden vastgesteld dat het ene woord het andere woord versterkt, is er sprake van meer afzonderlijk te benoemen intensiveringen:

Dat was echt fantastisch acteerwerk

$>$ Dat was fantastisch acteerwerk

Dat was fantastisch acteerwerk

$>$ Dat was goed acteerwerk

B.Van welke soort intensivering wordt gebruik gemaakt?

1. Intensiverend voorvoegsel

Een voorvoegsel is een betekenisdragend element (morfeem) dat vóór een woord is toegevoegd.Voorvoegsels kunnen gebonden zijn: dan komen ze uitsluitend in combinatie met andere morfemen voor; of ze zijn vrij: dan kunnen ze ook zelfstandig voorkomen. Bij analyse markeren we alleen het voervoegsel als intensivering.

Het is een topatleet

$>$ Het is een goede atleet

De hypermoderne aanpak oogst bewondering

$>$ De moderne aanpak oogst bewondering

2. Intensiverend bijwoord

Een bijwoord is een woord dat een nadere bijzonderheid (zoals een graad, omstandigheid, enz.) noemt van een door een gezegde of bepaling uitgedrukte werking, eigenschap of toestand.

a. Bijwoord van graad

Een bijwoord van graad duidt de mate aan waarin een bepaalde eigenschap van toepassing is. Voorbeelden van versterkende bijwoorden van graad zijn: uitermate, hoogst, erg, volstrekt, heel. De woorden te, al te en veel te horen thuis onder de categorie 'bijwoorden van modaliteit', behalve als ze in de variant 'te gek' (erg gek, gaaf) worden gebruikt.

De zeer geslaagde uitvoering van de derde symfonie ...

$>$ De geslaagde uitvoering van de derde symfonie

Dat is hartstikke interessant

$>$ Dat is zeer interessant

Dat is maar al te waar

$>$ Dat is waar

b. Bijwoord van frequentie of kwantiteit

Een bijwoord van frequentie geeft aan hoe vaak iets het geval is: voortdurend, dikwijls, telkens, altijd, vaak of steeds. 
Een bijwoord van kwantiteit geeft aan dat een eigenschap, toestand of werking ten volle of maar tot op zekere hoogte geldt. In combinatie met een telwoord geven bijwoorden van kwantiteit aan dat een bepaalde hoeveelheid bij benadering of juist volledig bereikt wordt: volkomen, helemaal, compleet, volslagen, vrijwel, praktisch, alom, verreweg

Hij heeft altijd succes met zijn optredens

$>$ Hij heeft succes met zijn optredens

Hij overschreed de maximum snelheid royaal

$>$ Hij overschreed de maximum snelheid

Zo'n pand kost bijna een miljoen euro

$>$ Zo'n pand kost iets minder dan een miljoen euro

c. Bijwoord van modaliteit

Een bijwoord van modaliteit geeft de subjectieve houding of waardering weer van de schrijver t.o.v. het in de zin uitgedrukte.Voorbeelden zijn uiteraard, inderdaad, hopelijk, helaas.

Tot deze groep rekenen we ook de oordeelspartikels (woorden met een moeilijk te omschrijven betekenis, die de uiting subjectief kleuren maar niets aan de feitelijke inhoud afdoen of toedoen): zelfs, juist, alleen, slechts, al, reeds, nog, pas, eerst, te, al te, veel te.

Dat is uiteraard een blunder $>$ Dat is een blunder

Hij greep pas in na herhaald aandringen $>$ Hij greep in na herhaald aandringen

d. Adverbiaal gebruikt bijvoeglijk naamwoord

Een adjectief heet bijwoordelijk of adverbiaal gebruikt als het de functie van bijwoordelijke bepaling vervult. De traditionele grammatica spreekt dan van bijwoorden. Zie ook de omschrijving onder intensiverend bijwoord.

Dat heb je fantastisch gedaan

$>$ Dat heb je goed gedaan

Een luxueus uitgevoerd design product

$>$ Een duur uitgevoerd design product

e. Overige bijwoorden

De bovenstaande soorten bijwoorden zijn niet per definitie intensiverend, maar ze lenen zich wel heel goed voor intensiveringen. De proef op de som is steeds: is een formulering zonder het bijwoord mogelijk die zwakker is. Incidenteel zullen zich mogelijk ook andere soorten bijwoorden als intensivering aandienen. Die benoemen we echter niet apart. Als ze niet in een van de andere categorieën zijn op te nemen, rangschikken we ze onder overige bijwoorden.

De aanpak is wereldwijd geaccepteerd

$>$ De aanpak is overal geaccepteerd

3. Intensiverend telwoord

Onder deze categorie vallen hoofdtelwoorden, rangtelwoorden en breuken. Hoofdtelwoorden noemen een aantal of het nummer, rangtelwoorden geven de rangorde van iets in een 


\section{Over loodzware bassen en wapperende broekspijpen}

reeks aan en breuken worden gevormd door één hoofdtelwoord gevolgd door een rangtelwoord.

De telwoorden vallen uiteen in bepaalde telwoorden (een precies aantal of (rang)nummer) en onbepaalde telwoorden (een niet nader gespecificeerd aantal of (rang)nummer).

Enkele voorbeelden: beide, alle, allebei, alle twee, (geen) enkele, veel (+ nevenvormen), weinig (+ nevenvormen), zoveelste, talloze, laatste(in een reeks).

Jan had al honderd keer gevraagd om snoep

$>$ Jan had al vaak om snoep gevraagd.

Ik doe dit al voor de vijfentachtigste keer opnieuw

$>$ Ik heb dit al vaak opnieuw gedaan

4. Intensiverend bijvoeglijk naamwoord

Een bijvoeglijk naamwoord geeft een nadere bijzonderheid van zelfstandigheden aan. Dat kan een eigenschap zijn (een kenmerk, een kwaliteit en dergelijke) of een toestand. Ook de overtreffende trap van een bijvoeglijk naamwoord kan als intensivering optreden. Ook het bijvoeglijke naamwoord dat optreedt als een zinsdeel (naamwoordelijk deel van het gezegde), rekenen we tot deze categorie.

Een abjecte benadering als deze lost het probleem niet op.

$>$ Een onaanvaardbare benadering ...

Alleen met de grootste moeite wist hij zijn voorstel geaccepteerd te krijgen $>$ Alleen met veel moeite ...

Het begin van de film is indrukwekkend $>$ Het begin van de film is geslaagd

5. Intensiverend zelfstandig naamwoord

Een zelfstandig naamwoord wordt wel omschreven als een woord dat een zelfstandigheid uitdrukt, maar dat begrip is te ruim om goed hanteerbaar te zijn. Syntactisch geldt als proef op de som of het woord met een voorafgaand die of dat valt te combineren.

Een dergelijke vertoning kan een politicus zich maar één keer veroorloven

$>$ Een dergelijk optreden kan ...

Voor de direct betrokkenen is het een ramp

$>$ Voor de direct betrokkenen is het een nadeel

6. Intensiverend werkwoord (inclusief werkwoordelijk uitdrukking)

Een werkwoord is een woord dat kan worden vervoegd: het neemt onder invloed van persoon en getal van het onderwerp in de zin een andere vorm aan (loop, loopt, lopen) en het kent een deelwoord en een infinitief (gelopen, lopen).

Een werkwoordelijke uitdrukking is een combinatie van werkwoorden met andere taalelementen die een gemeenschappelijke (niet figuurlijke) betekenis hebben en onveranderlijk zijn (ze staan in de Van Dale).Voorbeelden zijn: er van door gaan, tekeergaan tegen.

NB: als zelfstandig naamwoord gebruikte infinitieven rekenen we onder de zelfstandige naamwoorden (het eerste optreden). 
De heren zaten smakelijk te schransen

$>$ De heren zaten smakelijk te eten

De jongen flikkerde zijn spullen op tafel

$>$ De jongen gooide zijn spullen op tafel

Hij ging er van door

$>$ Hij vertrok

7. Intensiverende stijlfiguren

a. Versteende beeldspraak

Van beeldspraak is sprake wanneer een object, eigenschap, toestand of proces wordt vergeleken met of vervangen door een ander (veelal) meer concreet object, eigenschap, toestand of proces.

We vatten een beeldspraak op als versteend of gelexicaliseerd wanneer de figuurlijke betekenis tot de vaste woordenboek-betekenis van de betreffende lexicale eenheden behoort (zie in twijfelgevallen Van Dale).

Tot beeldspraak rekenen we: vergelijking (je vergelijkt iets met iets anders, ingeleid door als of aangeduid met lijken), metafoor (je benoemt iets met andere, meer beeldende woorden), synesthesie (een combinatie van indrukken van verschillende zintuigen).

Hij ging er als een haas vandoor (vergelijking)

$>$ Hij ging er snel vandoor

De verkoop kelderde snel (metafoor)

$>$ De verkoop daalde snel

Piet is een boom van een kerel (metafoor)

$>$ Piet is er groot

Het decor schreeuwde om aandacht (synesthesie)

$>$ Het decor trok veel aandacht

b. Originele beeldspraak

Wanneer beeldspraak niet in het woordenboek is te vinden onder één van de lexicale elementen, beschouwen we het als een originele vorm van beeldspraak (met een figuurlijke betekenis).

Tijdens de drumsolo's was het dekking zoeken

$>$ De drumsolo's waren te hard

Een echte gitaarbeul ontbrak

$>$ Een gitarist met wat steviger spel ontbrak

c. Herhaling

Een uiting kan meer nadruk krijgen door herhaling of opsomming. Dat kan op verschillende manieren: door herhaling van hetzelfde woord (repetitio), herhaling van hetzelfde met verschillende woorden van dezelfde woordsoort (tautologie), herhaling met gebruikmaking van verschillende woordsoorten (pleonasme) of opsomming van een reeks met climax of anticlimax (enumeratie). We rekenen ze allemaal tot de herhaling als stijlfiguur.

Geld, geld is het enige dat hem bezig houdt

$>$ Geld is het enige dat hem bezig houdt

Dat is vast en zeker waar 
Over loodzware bassen en wapperende broekspijpen

$>$ Dat is waar

Aan een treurigmakende troosteloosheid viel hierbij niet te ontkomen

$>$ Aan troosteloosheid viel hierbij niet te ontkomen

Er waren geen tien, geen twintig, geen vijftig, maar honderd bezoekers

$>$ Er waren honderd bezoekers

d. Hyperbool

Een uiting kan meer nadruk krijgen door een overdreven manier van uitdrukken.

We moesten een eeuw wachten

$>$ We moesten lang wachten

Door klimaatverandering dreigt Nederland onder de zeespiegel te verdwijnen

$>$ Door klimaatverandering neemt het gevaar van overstroming in Nederland toe

e. Overige stijlfiguren

De bovenstaande stijlfiguren zijn niet per definitie intensiverend, maar ze lenen zich wel heel goed voor intensiveringen. De proef op de som is steeds: is een formulering zonder stijlfiguur mogelijk die zwakker is. Incidenteel zullen zich mogelijk ook andere stijlfiguren als intensivering aandienen. Die benoemen we echter niet apart. Als ze niet in een van de andere categorieën zijn op te nemen, rangschikken we ze onder overige stijlfiguren.

Ik vind dat geen verkeerd plan $>$ Ik vind dat een erg goed plan

8. Syntactische intensiveringen (intensiverend verbindingswoord, elliptische zinnen, vooropplaatsing)

- De syntaxis van een zin kan ervoor zorgen dat het geformuleerde een intensiverende werking krijgt.Voorbeelden van deze syntactische intensiveringen zijn het intensiverend verbindingswoord, een elliptische zin en vooropplaatsing.

- Een intensiverend verbindingswoord verbindt twee of meer naast elkaar geplaatste, gelijkwaardige leden met elkaar.

- Een zin bestaat uit een verzameling woorden en bevat een onderwerp en een werkwoordsvorm. Echter, in een elliptische zin ontbreekt de werkwoordsvorm.

- Bij vooropplaatsing wordt een deel van de zin voorop geplaatst. Hiermee wordt de aandacht extra op dit deel gevestigd.

Zowel de voorzitter als de vice-voorzitter zijn het eens met het standpunt.

$>$ De voorzitter en de vice-voorzitter zijn het eens met het standpunt.

Jan: "Zij hebben het tentamen gehaald." Kees: "Hij niet!"

> Jan:"Zij hebben het tentamen gehaald." Kees:"Hij heeft het niet gehaald!"

Op een tiende haalde hij zijn examen.

$>$ Hij haalde zijn examen op een tiende.

9. Typografie

Met de typografie wordt de tekst gezet, gedrukt en vormgegeven. Het gaat hierbij om leestekens en de manier waarop een tekst is weergegeven. Hierbij spelen opmaak, lettertype, lettergrootte, accenten, vetgedrukt, onderstreept, interpunctie, tussen haakjes plaatsen etc. een rol. Deze typografische middelen kunnen op sommige woorden of tekstdelen meer de nadruk leggen.

Dát was echt GEWELDIG!

$>$ Dat was echt geweldig. 